\title{
HYDROLYTIC ACTIVITY OF BACTERIAL LIPASES IN AMAZONIAN VEGETABLE OILS
}

\author{
André Luis Willerding*, Francisco Geraldo Mello da Rocha Carvalho Neto, Auricélia Matos da Gama e Cláudia Regina \\ Ferreira Carioca \\ Coordenação de Bioquímica e Biologia Molecular, Centro de Biotecnologia da Amazônia, Av. Gov. Danilo Areosa, 690, \\ 69075-351 Manaus - AM, Brasil \\ Luiz Antonio de Oliveira \\ Laboratório de Microbiologia do Solo, Instituto Nacional de Pesquisas da Amazônia, CP 478, 69011-970 Manaus - AM, Brasil
}

Recebido em 8/2/12; aceito em 7/5/12; publicado na web em 10/8/12

\begin{abstract}
The data presented describe the development of an enzymatic process in vegetable oils. Six bacterial lipases were tested for their ability to hydrolyze. For each lipase assay, the p-NPP method was applied to obtain maximum enzymatic activities. The lipase from Burkholderia cepacia (lipase B-10) was the most effective in buriti oil, releasing $4840 \mu \mathrm{mol} \mathrm{p-NP} \mathrm{mL}^{-1}$. The lipase from Klebsiella

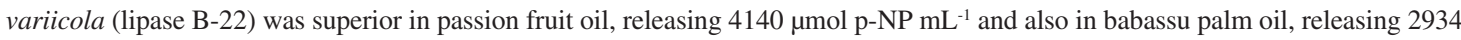
$\mu \mathrm{mol} \mathrm{p}-\mathrm{NP} \mathrm{mL}^{-1}$. Research into the bioprocessing of oils aims to provide added value for this regional raw material.
\end{abstract}

Keywords: lipase; enzymatic hydrolysis; Amazonian oils.

\section{INTRODUCTION}

World production of vegetable oils rose from 70 million tonnes in 1997 to 95 million tonnes in $2001 .{ }^{1}$ In 2010, world consumption of vegetable oils had increased by $27 \%$ in 10 years, reaching 121 tonnes due to demand from food and fuel sectors. Oil palm trees play an important role in the global economy, producing more than 30 million tonnes of oil per year. ${ }^{2}$

In the Amazon, there are countless species whose products can contribute to meet the demand for seeds, fruit, nuts and their oleaginous oils. ${ }^{3,4}$ In this context, the Amazon appears a promising resource and source of economic opportunity that can strike a balance between regional development and environmental conservation by bioindustries. $^{5}$

However, despite this privileged situation with regard to their biodiversity, forest resources in the region are generally sold only as raw material, with little or no added value. ${ }^{6}$ Thus, the use of native species and their products in (bio)industrialization represents a business opportunity that will certainly have a multiplier effect on the regional economy. The processing of vegetables oils by enzyme technology is a biotechnological tool for potential economic and sustainable development in the region. Currently, the conversion of fats and oils into products with high added value such as monoacylglycerides, diacylglycerides and free fatty acids produced through lipase-catalysis have been of great industrial interest. ${ }^{7}$

Despite their increasing use by cosmetic and pharmaceutical industries, oils from the Amazon remain little exploited commercially. ${ }^{8,9}$ Among the most commercially attractive are fats and oils obtained from Theobroma cacao (cacau), Virola surinamensis (ucuuba), Copaifera multijuga (copaíba) and Carapa guianensis (andiroba). ${ }^{10}$ Other palms such as babassu (Orbignya phalerata) and buriti (Mauritia flexuosa) stand out as potential sources of beta-carotene, fatty acids, and monoglycerides. But despite this diversity and potential, the vast majority of these species has not been explored extensively. ${ }^{2}$

Buriti oil is an important source of vitamins, protein and energy and has great utility in the region. ${ }^{6}$ The buriti fruit can produce two

\footnotetext{
*e-mail: andre.cba@suframa.gov.br
}

types of oil with potential use in chemical and food industries. From the fruit pulp, oils rich in oleic acids are extracted while seeds are rich in lauric acid. The pulp oil is considered a major source of carotene (pro-Vitamin A) in nature. ${ }^{11,12}$ This characteristic makes this oil usefum for the manufacture of sunscreen. ${ }^{13,14}$

The cashew (Anacardium occidental) is native of Brazil, but India is the world's largest producer of cashew nuts and nut oil, accounting for $90 \%$ of production. In Brazil, production of the oil takes place in the North and Northeast regions. The cashew nut has a shell with viscous oil containing a caustic resin. The nut is the main product, rich in oil. The oil has a broad array of industrial applications, and can be used in fungicides, insecticides, germicides, photographic developers, anti-oxidants, abrasives, friction post, among many others. Also, the oil boasts antiseptic and vermifuge properties. ${ }^{15}$

The passion fruit (Passiflora edulis) is a tropical plant with broad geographic distribution. Currently, Brazil is the world's leading producer of passion fruit. The oil is extracted from the seed, with a yield of $25 \%$ and has relaxing substances with an aroma which reduces anxiety, improves sleep, while reducing stress and fatigue in general. The oil has a very wide application in cosmetics, creams, shampoos, lotions, oils, soaps, and can be used both in food and feed industries. ${ }^{3}$

The babassu is the palm native of Northern Brazil and has multiple seeds or kernels from which the oil is extracted. Extraction from seeds yields 65 to $68 \%$ white to slightly yellowish oil. This color depends on temperature due to the high concentration of lauric acid (C12:0). The oil has many applications including in the cosmetic industry, food, soap, coconut soap, detergents and lubricants. The market for babassu oil is facing a crisis due to competition from palm oil from Asia. Babassu oil has the highest rate of saponification and a low iodine value and refractive index, rendering it suitable for the preparation of creamy ointments. ${ }^{11}$

The processing of oils and fats is predominantly based on conventional chemical processes. ${ }^{16}$ Although these changes can be easily achieved by chemical methods, these have some disadvantages such as the use of high temperatures, formation of byproducts during the reaction, plus the need for additional operations to purify the end product, as well as for high pressures and non-specificity of the catalysts. ${ }^{3}$

Among the different oil technologies, hydrolysis aims to produce free fatty acids (FFA), partial glycerides and glycerol. Enzymatic 
hydrolysis (catalyzed by lipases E.C. 3.1.1.3) has some advantages over conventional chemical processes because enzyme reactions require lower temperatures, which prevents the degradation of products and reduces energy costs. Furthermore, enzymes are biodegradable and consequently are less polluting than chemical catalysts. ${ }^{17}$ Typically, the hydrolysis yield exceeds $97 \%$ and the final mixture must be distilled to remove the byproducts formed during the reaction. ${ }^{18}$

Fatty acids and their derivatives are essential raw materials obtained from animal fat and vegetable oils. ${ }^{19}$ Enzymatic hydrolysis has been gaining ground as an alternative to physical and chemical processes. Usually, lipolytic enzymes are characterized by their ability to catalyze a broad range of reactions of interest to the food, pharmaceutical, chemical and other industries. With this versatility is also the possibility of substrate specificity involving lipases from various sources. ${ }^{10}$

In this paper, we evaluated the hydrolytic performance of 6 lipases for the production of FFA. In addition, preliminary optimization to determine the optimal processing parameters for the enzymatic hydrolysis was carried out.

\section{EXPERIMENTAL}

\section{Microbial production and determination of lipase activities}

The biological material was part of the Soil Microbiology Collection of INPA. The bacterial strains tested for lipase activity were selected after screening by Willerding et al. ${ }^{20}$ A set of 181 bacterial isolates was tested in a culture medium as inductor. Of this total, 75 bacterial isolates (41\%) showed production of lipase. Thus, 6 lipase-producing strains originally isolated were used.

\section{Determination of fatty acid composition}

The vegetable oil samples were donated by Crodamazon (buriti), Cupuama (passion fruit), UFAM/LAPEC - Laboratory fuel (babassu) and through private donations for cashew oil from Roraima, Brazil. All oils were extracted from the pulp of the fruit or nut by mechanical extraction. The extraction yield was not informed. For each unhydrolyzed oil fatty acids were converted after hydrolysis into fatty acid methyl esters (FAME). ${ }^{21}$ Their compositions were determined by gas chromatography (GC) (Shimadzu, model GCMS-QP-2010) on a DB-Wax column (Agilent), at an initial temperature of $60{ }^{\circ} \mathrm{C}$, $25{ }^{\circ} \mathrm{C} \mathrm{min}-1$, and final temperature of $230{ }^{\circ} \mathrm{C}$. The temperature of the injector was $250^{\circ} \mathrm{C}$ and the detector's temperature was $250^{\circ} \mathrm{C}$. Fatty acids were identified by comparing the times of retention of the components present in each sample with the times of retention of the components present in the standard FAME Mix C4-C24 (Sigma).

\section{Enzyme activity}

A liquid culture medium containing oil for inducing lipase production was prepared ( $\mathrm{pH} 8.0)$ :oil (2.0\%), Tween 80 (1\%), peptone $(0.3 \%)$, yeast extract $(0.2 \%), \mathrm{KH}_{2} \mathrm{PO}_{4}(0.2 \%), \mathrm{MgSO}_{4}(0.1 \%)$ and $\mathrm{CaCl}_{2}(0.1 \%)$ with cultures incubated at $30{ }^{\circ} \mathrm{C}, 72 \mathrm{~h}$ and $120 \mathrm{rpm}$.

After fermentation, the medium was collected and centrifuged at $4{ }^{\circ} \mathrm{C}$ at $12,000 \mathrm{rpm}$ for $30 \mathrm{~min}$ to obtain the crude enzymatic extract, which was used to determine lipase activity in p-nitrophenylpalmitate (p-NPP/Sigma $\left.{ }^{\circledR}\right)$. A solution of $\mathrm{p}-\mathrm{NPP}(2.5 \mathrm{mmol})$ in sodium acetate buffer ( $\mathrm{pH} 8.0,50 \mathrm{mM}$ ) was then prepared. An aliquot of $950 \mathrm{~mL}$ of this solution was added to another aliquot of $50 \mathrm{~mL}$ of the solution of the crude extract of each isolate, followed by reaction at $37{ }^{\circ} \mathrm{C}$ for $15 \mathrm{~min}$, with the absorbance reading at $410 \mathrm{\eta m}$ compared with that of the standard curve for para-nitrophenol (p-NP). One activity unit (U) was defined as the amount of enzyme that released $1 \mu \mathrm{mol}$ de $\mathrm{p}-\mathrm{NP} \mathrm{mL}^{-1}$ under the conditions of the test, which was conducted in triplicate. This step served to select each enzyme with respect to its affinity for each oil tested. Subsequently, we applied a standard factorial design for the hydrolysis process..$^{22,23}$

\section{Experimental design}

With the aim of maximizing the process of hydrolysis, the strategy involves use of a Rotational Central Composite Design (DCCR) to obtain the optimum values of the significant variable considering the 3 variables: temperature $\left({ }^{\circ} \mathrm{C}\right)$, enzyme (\% compared to oil) and ratio of oil buffer (0.1 M Tris-HCl, $\mathrm{pH} 8.0)$ (Table 1$)$. The reaction progress was monitored for $3 \mathrm{~h}$ of reaction.

Table 1. Input variables and their levels using Response Surface Methodology

\begin{tabular}{lccccc}
\hline Variables & -1.68 & -1 & 0 & 1 & 1.68 \\
\hline Temperature $\left({ }^{\circ} \mathrm{C}\right)$ & 31.6 & 35 & 40 & 45 & 48.4 \\
Enzyme $(\%)$ & 1 & 2 & 3 & 4 & 5 \\
Oil:Buffer & $1: 1$ & $1: 2$ & $1: 3$ & $1: 4$ & $1: 5$ \\
\hline
\end{tabular}

The study was conducted in such a way as to allow assessment of the combination of input variables statistically significant for response. ${ }^{24}$ We used the same unit of enzyme activity for each extract tested, determining the response variable or independent release of fatty acid $\left(\% F F A=\frac{N x 28.2 x V}{m}\right)$, where: $\mathrm{N}$ - normality of the real solution of potassium hydroxide, $\mathrm{V}$ - volume of $\mathrm{KOH}$, solution spent in titration $(\mathrm{mL}), \mathrm{m}$ - sample mass of oil used in the tests $(\mathrm{g})$. The calculation of $\%$ free fatty acid was performed according to AOCS. ${ }^{25}$

The results were evaluated by analysis of variance (ANOVA) and bar chart (Pareto Graph). Due to the high variability inherent to bioprocesses involving enzymes and microorganisms, the parameters were considered significant at a p-value less than $10 \% .^{3,26}$

\section{Determination of bacterial species}

The bacterial isolates were identified based on partial sequencing of $16 \mathrm{~S}$ rRNA. The primers used for the bacteria were Primer 1F (GAGAGTTTGATCCTGGCTCAG-5'-3') and Primer 2R (CGGTGTGTACAAGGCCCGGGAACG 5'-3') for the PCR amplification. The amplification reaction was based on Sambrook $^{27}$ with some modifications to increase the efficiency of amplification, according to the following protocol: reaction buffer $(50 \mathrm{mM}$ Tris- $\mathrm{HCl}$, $\mathrm{pH}$ 8.0, $50 \mathrm{mM} \mathrm{NaCl}, 2.5 \%$ Triton X 100), dNTPs (200 mM each), $0.2 \mathrm{mM} \mathrm{MgCl}, 0.25 \mathrm{mM}$ of each primer, $0.8 \mathrm{ng} / \mathrm{uL}$ DNA sample and $0.02 \mathrm{U}$ Taq DNA polymerase. Amplification was performed in a thermocycler Eppendorf ${ }^{\circledR}$ - Mastercycler Gradient Model and the basic program consisted of 30 cycles (initial denaturation at $94{ }^{\circ} \mathrm{C}$ for $3 \mathrm{~min}$; subsequent denaturing, at $94{ }^{\circ} \mathrm{C}$ for $30 \mathrm{~s}$, annealing at $60{ }^{\circ} \mathrm{C}$ for $30 \mathrm{~s}$, extension at $72{ }^{\circ} \mathrm{C}$ for $2 \mathrm{~min}$ and $10 \mathrm{~min}$ for final extension). After PCR, the reaction product was purified with a GFX PCR ${ }^{\circledR}$ kit (Invitrogen $^{\circledR}$ ) and sequenced on a MegaBACE ${ }^{\circledR}$ unit at the Federal University of Amazonas (UFAM).

\section{RESULTS AND DISCUSSION}

\section{Determination of fatty acid composition}

Unhydrolyzed oil fatty acids were converted after hydrolysis into fatty acid methyl esters (FAME) whose composition is shown 
in Table 2. Babassu oil differs in its chemical composition having a high content of saturated fatty acids (55\% lauric acid C12:0). The other three oils showed a higher percentage of unsaturated fatty acids, $79 \%$ oleic acid (C18: 1) for buriti oil and $60 \%$ oleic acid for cashew oil. Passion fruit oil showed $60 \%$ linoleic acid (C18: 2). These compositions are similar to those found in the literature.

Table 2. Chemical composition of oil fatty acids converted after hydrolysis into fatty acid methyl esters (FAME)

\begin{tabular}{cccccc}
\hline FAME & Structure & $\begin{array}{c}\text { buriti } \\
\text { oil }\end{array}$ & $\begin{array}{c}\text { passion } \\
\text { fruit oil }\end{array}$ & $\begin{array}{c}\text { babassu } \\
\text { oil }\end{array}$ & $\begin{array}{c}\text { cashew } \\
\text { oil }\end{array}$ \\
\hline Caprylic & C8:0 & & & $7.3 \pm 0.2$ & \\
Capric & C10:0 & & & $7.6 \pm 0.2$ & \\
Lauric & C12:0 & & & $55.0 \pm 0.9$ & \\
Myristic & C14:0 & & & $27.0 \pm 0.4$ & \\
Palmitic & C16:0 & $16.3 \pm 0.3$ & $11.0 \pm 0.9$ & $11.0 \pm 0.4$ & $8.8 \pm 0.6$ \\
Arachidic & C20:0 & & & & $0.6 \pm$ \\
Stearic & C18:0 & $1.3 \pm 0.8$ & $3.0 \pm 0.6$ & $7.4 \pm 0.3$ & $7.9 \pm 0.3$ \\
Palmitoleic & $\mathrm{C} 16: 1$ & $0.4 \pm 0.1$ & & & $0.4 \pm 0.1$ \\
Oleic & $\mathrm{C} 18: 1$ & $79.2 \pm 1.2$ & $20.0 \pm 1.3$ & $20.0 \pm 0,8$ & $60.3 \pm 1.1$ \\
Linoleic & $\mathrm{C} 18: 2$ & $1.4 \pm 0.2$ & $60.0 \pm 0.8$ & & $21.5 \pm 0.4$ \\
Linolenic & $\mathrm{C} 18: 3$ & $1.3 \pm 0.3$ & $5.0 \pm 0.7$ & & $0.5 \pm 0.2$ \\
\hline
\end{tabular}

\section{Hydrolytic activity}

Table 3 shows the degree of affinity between lipase and oil through the release of p-NP. Lipases have specific affinity towards esters, varying according to the chain length of fatty acids and their positions in the triglyceride. ${ }^{28}$ The results indicate these different specificities of the lipases tested.
Table 3. Hydrolytic activity ( $\mu \mathrm{mol} \mathrm{p}-\mathrm{NP} . \mathrm{mL}^{-1}$ ) of six lipases that were produced in submerged fermentation using four different oils*

\begin{tabular}{|c|c|c|c|c|}
\hline Lipase & $\begin{array}{c}\text { Buriti } \\
\text { oil }\end{array}$ & $\begin{array}{l}\text { Passion } \\
\text { fruit oil }\end{array}$ & $\begin{array}{c}\text { Babassu } \\
\text { oil }\end{array}$ & $\begin{array}{c}\text { Cashew } \\
\text { oil }\end{array}$ \\
\hline B-08 & 1777 (e) & 1579 (f) & 1660 (b) & 2189 (c) \\
\hline B-10 & 4840 (a) & 2149 (d) & $1629(\mathrm{bc})$ & 1596 (d) \\
\hline B-12 & $2730(\mathrm{c})$ & 3514 (b) & 2909 (a) & 2499 (a) \\
\hline B-16 & 2207 (d) & $1815(\mathrm{e})$ & $1575(\mathrm{c})$ & 1494 (e) \\
\hline B-17 & 2962 (b) & 3017 (c) & 2925 (a) & 2482 (a) \\
\hline B-22 & 2742 (c) & 4140 (a) & 2934 (a) & 2326 (b) \\
\hline
\end{tabular}

* Different letters within the parentheses indicate statistically significant differences (Tukey test $\mathrm{p}<0.05$ )

Tree lipases (B-22, B-17 and B-12) were most effective in babassu oil (Tukey test; $p<0.05$ ), producing 2934, 2925 and $2909 \mu \mathrm{mol}$ p-NP $\mathrm{mL}^{-1}$, respectively. Lipase B-22 was superior in passion fruit oil releasing $4140 \mu \mathrm{mol} \mathrm{p}-\mathrm{NP} \mathrm{mL}^{-1}$. This lipase was also superior in babassu oil $\left(2934 \mu \mathrm{mol} \mathrm{p}-\mathrm{NP} \mathrm{mL}^{-1}\right)$. It is important to note that there are differences in chemical composition between these two and this enzyme showed good affinity in oils with unsaturated (passion fruit) and saturated (babassu) fatty acids. Lipase B-10 was the most effective in buriti oil releasing $4840 \mu \mathrm{mol}$ p-NP $\mathrm{mL}^{-1}$. The lipases B-12 and $\mathrm{B}-17$ were most effective in cashew nut oil, although the results were low for hydrolysis (2499 and $2482 \mu \mathrm{mol} \mathrm{p}-\mathrm{NP} \mathrm{mL}^{-1}$, respectively).

\section{Statistical analysis}

Based on the results disclosed by hydrolytic activity, a factorial design standard was applied for four experiments: buriti oil $\mathrm{x}$ lipase B-10, passion fruit oil x lipase B-22, babassu oil x lipase B-22 and cashew oil x lipase B-12 (Table 4).

Table 4. Result of enzymatic hydrolysis to obtain free fatty acids (FFA\%) for oils $x$ enzyme assays according to the experimental matrix

\begin{tabular}{|c|c|c|c|c|c|c|c|}
\hline \multicolumn{4}{|c|}{ Factors } & \multicolumn{4}{|c|}{ FFA $\%$} \\
\hline Assay & $\left({ }^{\circ} \mathrm{C}\right)$ & Enzyme (\%) & $\begin{array}{l}\text { Oil: } \\
\text { Buffer }\end{array}$ & $\begin{array}{c}\text { Buriti oil } \\
\text { X } \\
\text { Lipase B-10 }\end{array}$ & $\begin{array}{c}\text { Passion fruit oil } \\
\text { X } \\
\text { Lipase B-22 }\end{array}$ & $\begin{array}{c}\text { Babassu oil } \\
\text { X } \\
\text { Lipase B-22 }\end{array}$ & $\begin{array}{c}\text { Cashew oil } \\
\text { X } \\
\text { Lipase B-12 }\end{array}$ \\
\hline $\mathrm{T} 01$ & $40^{\circ}(0)$ & $3 \%(0)$ & $1: 3(0)$ & 9 & 3 & 76 & 9 \\
\hline T02 & $35^{\circ}(-1)$ & $4 \%(1)$ & $1: 2(-1)$ & 12 & 5 & 73 & 10 \\
\hline $\mathrm{T} 03$ & $35^{\circ}(-1)$ & $2 \%(-1)$ & $1: 2(-1)$ & 11 & 4 & 56 & 12 \\
\hline T04 & $40^{\circ}(0)$ & $1 \%(-1.68)$ & $1: 3(0)$ & 11 & 5 & 77 & 15 \\
\hline T05 & $40^{\circ}(0)$ & $3 \%(0)$ & $1: 1(-1.68)$ & 13 & 3 & 49 & 15 \\
\hline T06 & $35^{\circ}(-1)$ & $2 \%(-1)$ & $1: 4(1)$ & 15 & 4 & 85 & 15 \\
\hline T07 & $45^{\circ}(1)$ & $4 \%(1)$ & $1: 4(1)$ & 12 & 6 & 84 & 16 \\
\hline T08 & $35^{\circ}(-1)$ & $4 \%(1)$ & $1: 4(1)$ & 11 & 5 & 84 & 15 \\
\hline T09 & $40^{\circ}(0)$ & $3 \%(0)$ & $1: 3(0)$ & 14 & 3 & 77 & 13 \\
\hline $\mathrm{T} 10$ & $31.6(-1.68)$ & $3 \%(0)$ & $1: 3(0)$ & 16 & 5 & 46 & 15 \\
\hline $\mathrm{T} 11$ & $45^{\circ}(1)$ & $4 \%(1)$ & $1: 2(-1)$ & 11 & 5 & 78 & 10 \\
\hline $\mathrm{T} 12$ & $40^{\circ}(0)$ & $3 \%(0)$ & $1: 5(1.68)$ & 12 & 3 & 88 & 15 \\
\hline $\mathrm{T} 13$ & $48.4^{\circ}(1.68)$ & $3 \%(0)$ & $1: 3(0)$ & 16 & 4 & 86 & 11 \\
\hline $\mathrm{T} 14$ & $45^{\circ}(1)$ & $2 \%(-1)$ & $1: 2(-1)$ & 13 & 5 & 78 & 12 \\
\hline $\mathrm{T} 15$ & $45^{\circ}(1)$ & $2 \%(-1)$ & $1: 4(1)$ & 15 & 3 & 85 & 10 \\
\hline $\mathrm{T} 16$ & $40^{\circ}(0)$ & $5 \%(1.68)$ & $1: 3(0)$ & 15 & 2 & 78 & 14 \\
\hline $\mathrm{T} 17$ & $40^{\circ}(0)$ & $3 \%(0)$ & $1: 3(0)$ & 14 & 4 & 77 & 9 \\
\hline
\end{tabular}


Table 5. Analysis of variance (ANOVA) of the test babassu oil x Lipase B-22 for the response variable (\%FFA)

\begin{tabular}{|c|c|c|c|c|c|c|}
\hline Source & DF & Seq SS & Adj SS & Adj MS & $\mathrm{F}$ & $\mathrm{P}$ \\
\hline Regression & 9 & 2023.73 & 2023.73 & 224.85 & 2.86 & 0.090 \\
\hline Linear & 3 & 1700.90 & 1700.90 & 566.96 & 7.22 & 0.015 \\
\hline Square & 3 & 150.45 & 150.45 & 50.15 & 0.64 & 0.614 \\
\hline Interaction & 3 & 172.37 & 172.37 & 57.45 & 0.73 & 0.565 \\
\hline Residual Error & 7 & 550.03 & 550.03 & 78.57 & & \\
\hline Lack-of-fit & 5 & 249.36 & 249.36 & 109.87 & 329.62 & 0.003 \\
\hline Pure error & 2 & 0.67 & 0.67 & 0.33 & & \\
\hline Total & 16 & 2573.76 & & & & \\
\hline
\end{tabular}

Table 4 shows the matrix of experimental design generated from the full factorial design containing input variables coded with tree center points. The levels and combinations of the variables tested and statistical analysis were prepared by the statistical computing program SGPLUS ${ }^{\circledast}$. Also, analysis of the results of the experiments was done using the statistical software Minitab ${ }^{\circledR} 16$ to build the response surface graphs and contour plot.

Table 4 shows the experimental results observed in the reactions according to the experimental matrix shown in Table 1, ranging from 2 to $88 \%$ FFA from the hydrolysis reactions. On average, the experiment involving the babassu oil showed the highest (average $=75 \%$ FFA) and passion fruit oil the lowest (average $=4 \%$ FFA) values. As the experiment was performed with a crude enzymatic extract, the values are relatively low compared with those reported in the literature, where the release of fatty acids generally exceeds $60 \%$. Only reactions involving babassu oil showed good results.

The factors studied and their levels contributed to the hydrolysis of Babassu oil by lipase B-22. The T12 assay $\left(40{ }^{\circ} \mathrm{C}, 3 \%, 1: 5\right)$ showed the best efficiency in the hydrolysis process ( $88 \%$ FFA). For experiments involving other oils there is a need to review the processes and determine other factors or their respective levels studied.

The factorial design for the hydrolysis of babassu oil with lipase B-22 was analyzed by analysis of variance (ANOVA). Table 5 shows the analysis of reaction parameter effects for hydrolysis. The interaction effects of three or more factors were discarded. ${ }^{29}$ ANOVA revealed that the main effects $\mathrm{A}=\mathrm{T}\left({ }^{\circ} \mathrm{C}\right)$ and $\mathrm{C}=$ Oil:Buffer were variables that statistically influenced release of fatty acid response $(\%$ FFA). This is evidenced by the magnitude of the P-value.

For these variables, the test of null hypothesis is rejected because the estimated values for the test were less than $5 \%(p<0.05)$, i.e., the effects are less likely to represent only $5 \%$ of noise. Variable B = Enzyme (\%) was not significant and all interactions (AA, BB, CC, $\mathrm{AB}, \mathrm{AC}, \mathrm{CB}$ ) were also not significant.

Using the significant parameters of the response, a model was proposed: $(\% \mathrm{FFA}=76.1785+13.8057 \mathrm{~A}+17.3671 \mathrm{C}$ where $\mathrm{A}=\mathrm{T}$ $\left({ }^{\circ} \mathrm{C}\right)$ and $\mathrm{C}=($ Oil:Buffer $\left.)\right)$. The model obtained describes the relationships between variables within the studied range, which can be confirmed by the coefficient of determination $\left(\mathrm{R}^{2}\right)$, whose value was 0.9862 , where $98.62 \%$ of results are explained.

According to the $\mathrm{F}$ test, the model can be considered good for predicting the response because the $F$ value obtained was 3.42, slightly higher than the tabulated value which is 3.31 for $10 \%$ significance.

This significance is examined in Figure 1 (Pareto Graph) that shows the largest statistical influence on the response of release of fatty acids (\% FFA) by the variables that are intercepted by the vertical line (rejection limit $\mathrm{p}<0.05$ ). Therefore, significant factors will be assessed using Response Surface in an attempt to improve the process of hydrolysis of passion fruit oil.

Figure 2 represents the contour lines for conversion of free fatty acid in the light of the significant variables $\mathrm{A}=\mathrm{T}\left({ }^{\circ} \mathrm{C}\right)$ and $\mathrm{C}=$

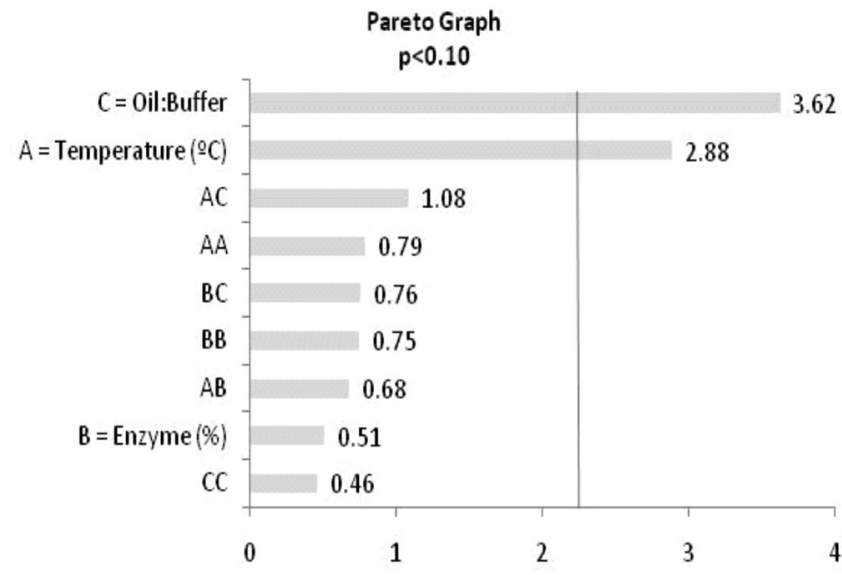

Figure 1. Pareto graph showing the effects of different variables on the concentration of $\%$ FFA

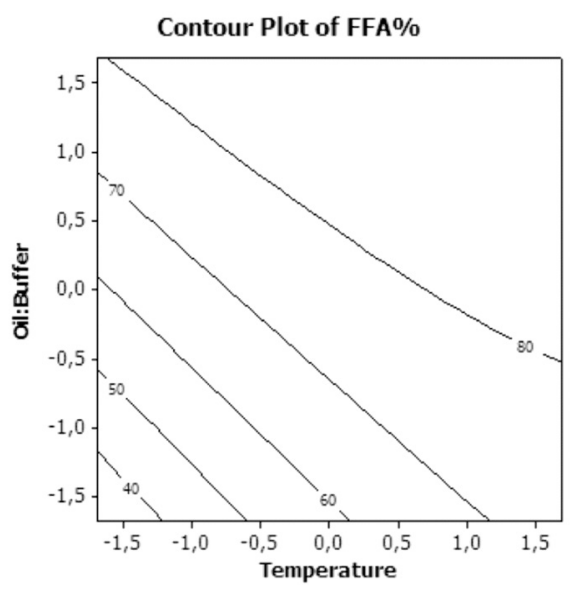

Figure 2. Contour plot for $\%$ FFA concentration as a function of temperature $\left({ }^{\circ} \mathrm{C}\right) x$ oil:buffer to the hydrolysis test with Babassu oil versus lipase B-22 (display plots using coded units)

(Oil:Buffer) for the test with Babassu oil versus lipase B-22.

Analysis of the contour plot graphs reveals an optimal region for the hydrolytic reaction of babassu oil. According to Figure 2, there is a range of high efficiency in hydrolysis directly proportional to the increase in oil: buffer (which increases the presence of water in the system) and also the increase of temperature in the reaction.

\section{Determination of bacterial species}

DNA homology is the molecular technique adopted as a consensus method for the determination of the bacterial species, although there are also biochemical and molecular techniques for differentiation of 
Table 6. Identification of bacterial strains based on partial sequencing of 16S ribosomal

\begin{tabular}{ccccc}
\hline & & & \multicolumn{2}{c}{ Identification } \\
Strain & Official Code & Acess & (16S rRNA) & Similarity \\
\hline B-08 & INPA P-124 & AY845053.1 & Burkholderia sp & \\
B-10 & INPA P-108 & AB252073.1 & Burkholderia cepacia & 100\% \\
B-12 & INPA P-799 & AB252073.1 & Burkholderia cepacia & $98 \%$ \\
B-16 & INPA P- 803 & EF113108.1 & Burkholderia cepacia & $99 \%$ \\
B-17 & INPA P-798 & AF335494.1 & Burkholderia cepacia & $99 \%$ \\
B-22 & INPA P-106 & AJ783916.1 & Klebsiella variicola & $98 \%$ \\
\hline
\end{tabular}

species, such as the lipidic profile of cytoplasmatic membranes. The objective was to show the genetic identification of the selected bacteria. Sequences of $16 \mathrm{~S}$ rDNA, genes encoding $16 \mathrm{~S}$ rRNA,${ }^{27}$ have been used to infer phyilogenetic relations where the criterion is most used to differentiate between bacteria species. The lipases occur widely in the biosphere where they are found in bacteria, fungus and yeasts. A variety of lipases of gram-positive and gram-negative bacteria have been purified, characterized biochemically, and undergone sequencing and cloning of their respective genes. Thus, identification of the selected bacteria is crucial since with this information it is possible to develop primers specific for the gene of the lipase. Comparison of only six selected bacteria, showed that four bacteria belonged to the type Burkholderia cepacia, (B-10; B-12; B-16 and B-17) while one was not identifiable (Burkholderia sp B-08), and the other was type Klebsiella (B-22) Table 6.

\section{CONCLUSION}

The proposed enzymatic process was not efficient for the four tests, but proved to be satisfactory for the experiment with babassu oil and lipase B-22. The best results were obtained with the reaction conducted at $40{ }^{\circ} \mathrm{C}, 3 \%$ for enzymes and an oil: buffer ratio of 1:5, yielding $88 \%$ conversion to free fatty acids. The model obtained describes the relationships between variables within the studied range, which can be confirmed by the coefficient of determination $\left(\mathrm{R}^{2}=0.9862\right)$ in explaining the results. The enzyme B-22 showed a preference for substrates of short to medium chain length. The affinity of this enzyme to the babassu oil can be important for the preparation of oil for biodiesel production in the hydroesterification process. Another application is for the obtention of lauric acid, an important input for the development of drugs to boost the immune or anti-inflammatory systems. For the other cases, a review of the factors and their levels is warranted in an effort to increase the efficiency of the process. Research into bioprocessing of vegetable oils is aimed at providing added value for this regional raw material.

\section{ACKNOWLEDGMENT}

We thank Crodamazon, Cupuama and the Federal University of Amazonas (UFAM) for the donation of the oil samples.

\section{REFERENCES}

1. Campo, I.; Revista Eco 21 2003. 80, 21.

2. Ebongue, G. F. N.; Dhouib, R.; Carriere, F.; Zollo, P. H. A.; Arondel, V.; Plant Physiol. Biochem. 2006, 44, 611.

3. Costa, D. S.; Silveira, B. I.; Anais do II Congresso Brasileiro de Termodinâmica Aplicada, Curitiba, Brasil, 2004.

4. Clement, C. R.; Lleras Pérez, E.; van Leeuwen, J.; Agrociencias 2005 , $9,67$.
5. ABC - Academia Brasileira de Ciências; Amazônia: desafio brasileiro do século XXI - a necessidade de uma revolução científica e tecnológica, Fundação Conrado Wessel: Rio de Janeiro, 2008.

6. Amazonas, Governo do Estado; Série Técnica Meio Ambiente e Desenvolvimento Sustentável no 6, SDS: Manaus, 2005.

7. Fregolente, P. B. L.; Pinto, G. M. F.; Wolf-Maicel, M. R.; Maciel Filho, R.; Batistella, C. B.; Quim. Nova 2009, 32, 1539.

8. Pallet, D.; Anais do Colóquio SYAL, Montpellier, França, 2002.

9. Albuquerque, M. L. S.; Guedes, I.; Alcantara Jr. P.; Moreira, S. G. C.; Barbosa Neto, N. M.; Correa, D. S.; Zílio, S. C.; J. Braz. Chim. Soc. 2005, 16, 1113 .

10. Gilbert, B.; Rev. Fitos 2006, 2, 30.

11. Arpigny, J. E.; Jaeger, K. E.; Biochem. J. 1999, 343, 177.

12. Silveira, B. I.; Costa, D. S.; Anais XV Simpósio Nacional de Bioprocessos, Recife, Brasil, 2005.

13. Crodamazon; Boletim Técnico - Óleo de buriti, Manaus, Brasil, 2002.

14. Albuquerque, M. L. S.; Guedes, I.; Alcantara Jr., P.; Moreira, S. G. C.; Vib. Spectrosc. 2003, 33, 127.

15. Joker, D.; Humlebaek: Danida Forest Seed Centre 2003, 21, 2.

16. de Castro, H. F.; Mendes, A. A.; dos Santos, J. C.; de Aguiar, C. L.; Quim. Nova 2004, 27, 146.

17. Cavalcanti-Oliveira, E.; Silva, P. R.; Ramos, A. P.; Aranda, D. A. G.; Freire, D. M. G.; Enzyme Research (2011): Article ID 618692. Published online. doi:10.4061/2011/618692.

18. Gioielli, L. A.; Pitombo, R. N. M.; Vitolo, M.; Barufaldi, R.; Olioveira, M. N.; Moreno, P. C.; Riv. Ital. Sostanze Grasse 1995, 72, 115.

19. Kobori, C. N.; Jorge, N.; Ciênc. Agrotec. 2005, 29, 1008.

20. Willerding, A. L.; Oliveira, L. A.; Moreira, F. W.; Germano, M. G.; Chagas Jr., A. F.; Enzyme Research (2011): Article ID 720194. Published online. doi:10.4061/2011/720194.

21. Maia, E. L.; Rodriguez-Amaya, D. B.; Rev. Inst. Adolfo Lutz 1993, 53, 27.

22. George, E.; Tamerler, C.; Martinez, A.; Martinez, M. J.; Keshavarz, T.; J. Technol. Biotechnol. 2003, 74, 137.

23. Pastore, G. M.; Costa, V. S. R.; Koblitz, M. G.; Ciênc. Tecnol. Aliment. 2003, 2, 135.

24. Rodrigues, M. I. Em Planejamento de experimentos e otimização de processos: uma estratégia sequencial de planejamentos; Rodrigues, M. I.; Iemma, A. F., eds.; Casa do Pão Ed.: Campinas, 2005, cap. 5.

25. AOCS; Official methods and recommended practices of the American Oil Chemists' Society, AOCS: Champaign, 1993.

26. Burket, J. F. M.; Maldonado, R. R.; Maugeri F ${ }^{o}$, F.; Rodrigues, M. I.; J. Chem. Technol. Biotechnol. 2005, 80, 61.

27. Sambrook, J.; Fritsch, E. F.; Maniatis, T.; Molecular cloning, CSHL Press: New York, 1989, vol. 1.

28. Snellman, E. A.; Sullivan, E. R.; Colwell, R. R.; Eur. J. Biochem. 2002, 269, 5771.

29. Box, G. E. P.; Hunter, W. G.; Hunter, J. S.; Statistic for experimenters, New York, 1978. 